\title{
Nominal Stance Construction in L1 and L2 Students' Writing
}

\begin{abstract}
The study of stance and how academic writers convey an attitude to their material and readers has become an important area of teaching research in EAP in recent years (Hyland \& Guinda, 2012). A relatively neglected means of stance expression, however, has been the Noun Complement structure. This study examines this structure as a nominal stance construction which is associated with students' advanced academic literacy. Through a corpus-based contrastive interlanguage analysis, this study compares the use of this stance construction in argumentative essays of 366 Chinese university students (L2) with those of 82 American students (L1) of similar age and educational level. Results show that the L2 students use significantly fewer instances of this construction especially in the event, discourse and cognition types of stance nouns, which are bound up with the generic conventions of argumentative essays. But they show a propensity to invest personal affect by pre-modifying the stance nouns with attitudinal adjectives and first-person possessives. The paper discusses a number of issues raised by the research and makes pedagogical suggestions for EAP writing instruction.
\end{abstract}

\section{Keywords}

stance; Noun Complement structure; nominalization; argument; academic literacy 


\section{Introduction}

A key aspect of proficient advanced academic writing is the ability to express an appropriate stance towards one's material and readers (Charles, 2007; Hyland \& Guinda, 2012). This is, however, a normally difficult feature for second language (L2) writers to control (Hyland \& Milton, 1997; Tang, 2012) and has become an important area of teaching research in EAP. A number of studies have been made on stance expression in students' writing in terms of hedges and boosters (Hyland \& Milton, 1997), appraisal (Lancaster, 2014), engagement (Wu, 2007) and metadiscourse (Ädel, 2006) and have come to regard adverbs, adjectives, reporting verbs, lexical bundles and so on as among a wide repertoire of stance features available to student writers (Cobb, 2003; Grant, \& Ginther, 2000; Hinkel, 2004). However, few studies have investigated how student writers encode evaluation in their texts specifically through nominal constructions. As Holmes (1988, p. 37) points out, "nominal constructions are a rather underrated epistemic strategy....and learners are not well served by the range provided". This present study therefore aims to explore the Noun Complement structure as an important stance construction and examine how L2 students present themselves and develop arguments through this stance device. The results of this study will further our understanding of students' stance expression in this form so as to provide effective writing instruction in EAP.

\section{Stance in argumentative essays}

For Biber (2006, p. 99), stance is the expression of the "personal feelings and assessments" that writers have "about certain information, how certain they are about its veracity, how they obtained access to the information, and what perspective they are taking". By taking a stance, writers not only express their epistemic and affective perspectives on knowledge but also engage their readers and build solidarity with them (Hunston, \& Thompson, 2000; Hyland, 2005). Stance also enables a writer to regulate the dialogic space for the negotiation of a proposition (Martin \& White, 2005; Wu, 2007). For student writers, what stances they project may “play a role in shaping readers' judgments of overall writing quality" (Lancaster, 2014, p. 28), having a connection with the grades or scores that students obtain (Barton, 1993; Wu, 2007). Thus it is sometimes referred to as "voice" that writing teachers expect to hear from students' essays (Ramanathan, \& Atkinson, 1999).

L2 students, however, exhibit varied problems in terms of the types of stance they take and the linguistic means they use. Typically they convey undue interpersonal involvement and lack lexical diversity and nuance when making evaluation in texts (Cobb, 2003; Grant \& Ginther, 2000). In Hyland \& Milton (1997)'s study, Cantonese speaking students found it pragmatically difficult to handle epistemic stance expression, with much reliance on limited lexical options of modal verbs and adverbs. McEnery \& Kifle (2002) show that L2 students use more tentative and weak devices when qualifying their claims. Students' inability to develop an appropriate stance undermines the argumentative effect of their academic essays (Wingate, 2012; Lancaster, 2014). Argument in essays carries a credible and persuasive force not only from a writer's propositional claim and the supporting factual "grounds and warrants", but also from the ability to "analyse and evaluate content 
knowledge" (Wingate, 2012, p. 146). Many L2 students find it difficult to project a competent position and form strong rhetorical organizations in essays, especially in the lack of "real evidence" to support their claims (Qin \& Karabacak 2010, p. 454).

Thus the mastering of stance construction helps students to negotiate views and structure arguments through the creation of a persuasive relationship between grounds and claims. However, the above studies show that L2 students have difficulties in this rhetorical endeavor, especially in the respect of what stance options they take and how they develop arguments through stance construction. We may also see the need to equip students with a wide repertoire of stance devices. Unfortunately little attention has been paid to the stancetaking affordances of nominal structure and this may have a side effect on the teaching of EAP writing.

This study examines the Noun Complement structure as a nominal stance construction, which offers writers the opportunity to foreground their position towards the content of a complement clause by selecting an appropriate head noun. By this study I seek to add to the current body of knowledge of L2 students' stance expression by comparing Chinese university students and American peers in the use of this nominal stance construction in academic essays.

\section{Noun complements and stance expression}

The Noun Complement construction is a grammatical structure in which a head noun together with its possible pre-modification takes a nominal complement either in the form of that clause, toinfinitive, of-prepositional or preposition plus wh-clause. Examples are given below.

(1) If we institute a prayer time or even a silent time there can be no assurance that students will utilize this period to reflect or to say the prayer with meaning. $<$ L1 $>1$

(2) Therefore it is our responsibility to respect and protect the privacy of famous people. $<$ L2 $>$

(3) In short, because no data shows that prayer actually causes a better educational or social environment there is no reason to allow for its inclusion into the public school. $<$ L1 $>$

(4) And students can have the benefits of using an E-dictionary in a proper way. $<$ L2 $>$

(5) Since a religious activity was permitted to occur on public school grounds after classes finished, there should not be a great controversy over whether students could utilize time after school to form a prayer group, a Bible or Koran study group. $<$ L1 $>$

Winter holds that head nouns in this structure, such as "assurance", "responsibility", "reason", "benefits" and "controversy" in the above examples, are unspecific in content without "lexical realization" for a full meaning from the subsequent complement clauses (Winter, 1982, p. 10). For

\footnotetext{
1 All examples come from the corpora described in the Section 4. They are marked $<$ L1 $>$ and $<$ L2 $>$ respectively with reference to their corpus source.
} 
example, "assurance" in sentence (1) is vague because we do not know what assurance refers to unless it is further specified in the sentence. From the perspective of reading and writing processes, the content of "assurance" should be specified somewhere inside or outside the text and in this sentence its full meaning is provided in the proposition of the following complement clause "students will utilize this period to reflect or to say the prayer with meaning". In the meantime, however, these head nouns convey writer's authorial perspective on the following complement information, so they are also called "stance nouns" 2 " to "denote their expression of the writer's point of view towards the content specified in the complement clause" (Author, 2015). The "responsibility" in example (2) refers to the proposition in its complement "to respect and protect the privacy of famous people". The complement proposition is seen not only as providing semantic equivalence of the head nouns as in examples (1) and (2) (Francis, 1986) but also as offering semantic completion as in the to-infinitive clause in example (3) (Author, 2015). Here the complement information does not semantically identify what the "reason" is but qualifies what the "reason" is for. Despite this difference, this study has included 'to complements' in the analysis to better understand the functioning of stance nouns and the contexts in which they operate.

Although these types of nouns have received some attention in the literature albeit under different names, such as "general nouns" (Halliday \& Hasan, 1976), "labels" (Francis, 1994), "carrier nouns" (Ivanič, 1991), "shell nouns" (Schmid, 2000) and "signalling nouns" (Flowerdew, 2003), these authors have overwhelmingly been concerned with the discourse-organizing functions of these nouns, focusing on the way they act as cohesive devices by cataphorically predicting or anaphorically encapsulating pieces of written discourse (Francis, 1994). Nevertheless, the choice of head noun does more than simply connect and organize discourse, playing a key role in the rhetorical construction of a writer's stance. It is a powerful persuasive device as the choice of noun foregrounds an author's assessment of what follows and turns it into an explicit statement of opinion with the potential for elaboration and further discussion.

The L2 writer in (6) chooses "phenomenon" (rather than "fact" or "reality" for example) to label the complement information "competition became more and more severe" possibly to show his or her perception of such description as "phenomenon". This choice indicates this student writer's judgment of the information in the complement as something not fully understood.

(6) The recent years has witnessed an unfavorable social phenomenon that competition have become more and more severe. $<$ L2 $>$

Thus a writer chooses a particular stance noun among a range of alternatives available to express his or her perspective and judgment of how the writer views the information and content in the complements. Furthermore, the Noun Complement structure as a stance construction foregrounds the writer's stance as the starting point of the complement message and the perspective

\footnotetext{
2 The terms of stance nouns and head nouns are interchangeably used in this study. Stance nouns are used with reference to stance expression while head nouns refer to grammatical structure.
} 
from which the content of complement clause is interpreted (Hyland \& Tse, 2005). In so doing, a presumption is built on readers of how to understand and interpret the information unfolded in the complement clause, which brings readers into the writer's stanced viewpoint and contributes to the construction and development of the writer's argument. Still in example (6), the stance noun "phenomenon" sets a frame that the coming information in the complement is defined as a phenomenon rather than a fact or reality and this presumption will influence readers' comprehension and interpretation of the complement information and readers may assume with the writer that "competition became more and more severe" is an issue that people do not fully understand. So the writer is empowered to subtly engage readers in alignment with his or her perspective and argument.

It is also noted that by adding different pre-modifications to stance nouns, writers are able to augment and reinforce their stance expression. This is typical of the pre-modifications in terms of attitudinal evaluative adjectives and first-person possessives (Hunston \& Thompson, 2000). More examples are given below. In example (7), the writer chooses "assumption" to position the complement information as unevidenced belief and then emphasizes his or her attitude by modifying the "assumption" as "false". Similarly, the writer in example (8) uses "my" to show his or her willingness to take the ownership and responsibility for the stanced "opinion".

(7) They are under the false assumption that many more people would commit more murders with only the threat of life imprisonment, than if the death penalty was implemented. $<$ L1 $>$

(8) With these three advantages of reading a book, you may support my opinion that books will never be substituted by Internet. $<$ L2 $>$

(9) Because the men's teams serve as the only role models, women have a better chance of avoiding many of the mistakes made by the men teams. $<\mathrm{L} 1>$

(10) In conclusion, it is our duty to protect others' privacy, only by doing that can we live harmoniously with others and live without worries. $<$ L2 $>$

We can also see in the above examples of stance-making a process of nominalization (Halliday \& Matthiessen, 2004) where the writers package an event or an action as a thing, so that the action to "protect others' privacy" in example (10) is objectified into a nominal form "duty". Halliday and Matthiessen (2004) comment that such a form of nominalization used in grammatical metaphor is associated with students' advanced level of literacy:

"Ideational metaphor, is learned later by children and is not part of the grammar of ordinary, spontaneous conversation that children meet in the home and neighbourhood; rather, it is associated with the discourses of education and science, bureaucracy and the law. Children are likely to meet the ideational type of metaphor when they reach the upper levels of primary school; but its full force will only appear when they begin to grapple with the specialized discourses of subject-based secondary education. " (Halliday \& 
Matthiessen, 2004, p. 636) [highlighted in this paper]

Clearly, such nominalization as the Noun Complement structure is beyond basic communicative skills but relates to advanced academic proficiency (Cummins, 1984). To illustrate, "a better chance of avoiding many of the mistakes made by the men teams" in example (9) is a case of nominalized process in which an action (or a process of a participant carrying an action in other cases) is abstracted and packaged into a nominal form ("avoiding many of the mistakes made by the men teams" is nominalized into "chance"). On the contrary, the basic communicative form, namely "the grammar of ordinary, spontaneous conversation that children meet in the home and neighbourhood" depicted in the quotation or the "congruent form" (Halliday \& Matthiessen, 2004, p. 508), which is more familiar to students, could be "women will probably avoid many of the mistakes made by the men teams". Flowerdew (2006) and Nesi \& Moreton (2012) found that the L2 students in their studies demonstrated less competence than their L1 counterparts in using nominalization, and their problems with this strategy are compounded by the different types of complement structures involved. It is meaningful for this study to observe how the Chinese learners handle this nominalized process in terms of different complement structures.

In sum, the Noun Complement construction, by offering a range of stance choices and the possibility of pre-modification, enables writers to construct a clear stance at the outset as a way of bringing readers into alignment with that stance and developing the writers' arguments. Considering what have been reviewed about the stance expression in L2 students' argumentative essays and the rhetorical characteristics of the Noun Complement structure, this study sets out to explore the following questions:

(1) What stance options do students select through choices of head nouns? How, if at all, do the L1 and L2 writers differ in their selections?

(2) What are the differences, if any, between L1 and L2 students in the use of complement structures?

(3) What are the differences, if any, between L1 and L2 students when they set up argument through the Noun Complement structure?

(4) How, if at all, do L1 and L2 students differ in the pre-modification to head nouns?

\section{Corpora and method}

This study compares two corpora of L1 and L2 students' argumentative essays, 192,580 words in total. The L1 corpus (95,277 words) was drawn from LOCNESS (Louvain Corpus of Native English Essays), consisting of 82 argumentative essays written by L1 American university students; L2 corpus (97,303 words) was extracted from WECCLE (Written English Corpus of Chinese Learners), comprising 366 argumentative essays written by Chinese L2 undergraduates majoring in English. Untimed essays were selected because they represent students' texts produced in relatively natural environment. Although the two corpora differ in the number of words per essay (1162 words in L1 writing and 266 words in L2 writing per essay on average), they are comparable due to the 
fact that they include a similar topic range ${ }^{3}$ and both groups of student writers are similar in age (18-22 years old) and educational level while at mixed years of study.

The approach of Comparative Interlanguage Analysis (Granger, 1998) was taken by this study as it aims to systematically compare various levels of linguistic features between "what non-native and native speakers of a language do in a comparable situation" in order to "uncover the features of non-nativeness of learner language" (Granger, 1998, p. 12-13). Along this line of inquiry, this study mainly identifies and analyzes the use of the Noun Complement construction and its premodifications in L2 students' writing compared with the L1 equivalence, giving less attention to erroneous uses because this study focuses more on stance making practice in argumentation. Although doubt has been raised about setting native speakers' language performance as the normative model for English learning (Ellis, 1994), to write and give voice as proficiently as native speakers is a high-priority for non-native English learners in academic contexts (Ädel, 2006; Hinkel, 2004; Hyland \& Milton, 1997).

The two corpora were part-of-speech tagged with CLAW 7 scheme before they were searched for the structures of $\mathrm{N}$ that clause, to-infinitive, of-prepositional and preposition plus wh-clause on the basis of syntactic information through regular expression query, using the commercial concordance software AntConc (Anthony, 2012). A manual reading of concordance lines was then done to improve the accuracy of the parsing and ensure all Noun Complement clauses had been identified. Following the compilation of the corpus and identification of $N$ complements, I then sought to create a categorization scheme for the stance nouns through careful analysis of concordance lines. I coded all the stance nouns using this scheme and analyzed their premodification as attitudinal evaluation or self-mention using $M A X Q D A$, a commercial qualitative data analysis tool (Kuckartz, 2007). Through the concordance lines, the frequency of different complement structures ( $\mathrm{N}$ that clause, to-infinitive, of-prepositional and preposition plus wh-clause) was also counted in order to observe whether there are any significant differences between L1 and L2 students in the process of nominalization.

\section{Categorization of stance nouns}

In developing the categorization, I was aware of earlier work in the literature. Previous studies, however, have largely focused on the semantic rather than the functional characteristics of these nouns. Schmid (2000), for example, classifies them as factual, linguistic, mental, modal, eventive and circumstantial types. Thus, for him, the noun "advantage" falls into the factual group presenting the complement information as uncontested. Unfortunately this overlooks its role in conveying a writer's positive evaluation of an entity or action, as in this example:

(11) Merton would further argue that most welfare recipients never had the advantage of growing up in a family in which a work ethic and responsibility

\footnotetext{
3 A list of the topics involved in the argumentative essays is provided in Appendix.
} 
to the family were emphasized. $<\mathrm{L} 1>$

As a result of these difficulties, I sought to devise a functional classification in order to see what stance options students made through choices of head nouns. After numerous passes through the corpora, the classification in Table 1 was produced. This shows that head nouns are functionally used either to mark entities, describe attributes of entities or discuss the relations between entities.

Table 1 Classification of stance nouns in the Noun Complement construction

\begin{tabular}{|c|c|c|}
\hline Entity & description & examples \\
\hline object & Concretizable meta-texts & essay, report, paper \\
\hline event & events, processes, states of affairs & change, process, evidence \\
\hline discourse & $\begin{array}{l}\text { verbal propositions and speech } \\
\text { acts }\end{array}$ & argument, claim, conclusion \\
\hline cognition & cognitive beliefs and attitudes & decision, idea, belief, doubt \\
\hline Attribute & description & examples \\
\hline quality & $\begin{array}{l}\text { traits that are admired or } \\
\text { criticized, valued or depreciated }\end{array}$ & advantage, difficulty, value \\
\hline manner & $\begin{array}{l}\text { circumstances of actions and state } \\
\text { of affairs }\end{array}$ & means, method, way, extent \\
\hline status & $\begin{array}{l}\text { epistemic, deontic and dynamic } \\
\text { modality }\end{array}$ & $\begin{array}{l}\text { possibility, trend, choice, } \\
\text { ability }\end{array}$ \\
\hline Relation & description & examples \\
\hline $\begin{array}{l}\text { cause-effect, } \\
\text { difference, etc. }\end{array}$ & $\begin{array}{l}\text { cause and effect, difference, } \\
\text { relevance }\end{array}$ & reason, effect, grounds \\
\hline
\end{tabular}

Nouns which refer to entities do so by either orienting to objects, events, discourses or aspects of cognition. Nouns representing objects refer to concrete things, usually texts, so that examples such as essay, report and paper are typical in this category. Event nouns refer to actions, processes or states of affairs which have a spatiotemporal location and examples such as change, process and evidence are frequently used. Discourse nouns take a stance towards verbal propositions and speech acts, such as argument, claim and conclusion while Cognition nouns concern beliefs, attitudes and elements of mental reasoning, such as decision, idea, assumption and doubt.

Nouns relating to attributes concern judgments and evaluations of the quality, status and formation of entities. Thus nouns pertaining to quality assess whether something is admired or criticized, valued or depreciated. Here assessments fall on a scale of plus or minus (e.g. good-bad and important-unimportant), typically involving nouns such as advantage, difficulty and danger. 
Nouns relating to manner, in contrast, describe the circumstances and formation of actions and states of affairs. Nouns such as means, method, way and extent depict either their dimensions in the way in which they are carried out or the frequency with which they occur. Stance nouns which concern status make judgment of epistemic, deontic and dynamic modality. Epistemic modality concerns possibility and certainty such as likelihood and truth; deontic modality bears on obligation and necessity such as need and obligation; dynamic modality describes ability, opportunity and tendency such as ability, potential and tendency.

It is, however, necessary to address the question whether 'the fact that...' should be seen as either a representation of reality or a judgment of certainty; whether it concerns an event or an attribute. In this I follow Labov's (1972) emphasis on the comparative nature of evaluation which helps to identify an evaluation. For him, evaluation occurs when a reference in a statement is compared to or contrasted with some background information or values (Labov, 1972, p. 381; Thompson \& Hunston, 2000, p. 13), as in this example:

(12) Advocates for people without homes tend to get so wrapped up in the size of the homeless population that they ignore the fact that it is not right that this discrepancy exists. $<$ L1 $>$

The verb "ignore" before "the fact that" clause here denotes a contrast between "Advocates for people without homes tend to get so wrapped up in the size of the homeless population" and "it is not right that this discrepancy exists", suggesting that "the fact that" is an expression of epistemic evaluation commenting on the likely certainty of "it is not right that this discrepancy exists" rather than an evidential reality. So in this case "fact" presents this L1 student writer's judgment of the epistemic status of an entity rather than an assertion of verifiable truth and is categorized in the status group.

Finally in my categorization, head nouns are also used to express a stance by elaborating how a writer understands the connection or relationship to information in a proposition, conveying relations such as reason, result and difference.

This function-based classification of head nouns therefore offers us a way to categorize the possible stances that student writers take up in their texts, conveying their attitudes towards the proposition that follows in the complement.

\section{Results and discussion}

Overall, there are 957 cases in total and 49.7 occurrences per 10,000 words of the Noun Complement structure found in both the L1 and L2 corpora and L2 students use this structure significantly less frequently than L1 students ( 53.9 vs. 45.6 cases per 10,000 words, log Likelihood $=0.90, p<0.01$ ). While L1 writers use the structure approximately $18.5 \%$ more than L2 writers per 10,000 words, the individual essay-based mean frequency by L2 students $(M=16.2, S D=0.55)$ is nearly 4.1 times lower than $\mathrm{L} 1$ counterparts $(M=66.2, S D=3.60)$ if individual variations among 
students are taken into account. Significant differences between L1 and L2 students' writing in terms of stance nouns, complement structure, discoursal level and pre-modifications will be reported and discussed respectively as follows.

\subsection{Stance nouns}

Even though type/token ratio of stance nouns used by L1 and L2 students does not indicate much difference ( 0.28 in L1 corpora vs. 0.26 in L2 corpora), differences appear evident when the stance nouns are categorized according to the function-based classification. Table 2 shows the distribution and frequency of stance nouns between L1 and L2 writing per 10,000 words and the percentage of each stance noun group.

Table 2 Distribution and frequency of stance nouns between L1 and L2 writing per 10,000 words (\% of total)

\begin{tabular}{|c|c|c|}
\hline $\begin{array}{c}\text { per } 10,000 \text { words } \\
\text { (\% of total) }\end{array}$ & L1 students & L2 students \\
\hline Entity & $\begin{array}{c}28.4 \\
(52.8)\end{array}$ & $\begin{array}{c}17.2 \\
(37.7)\end{array}$ \\
\hline object & $\begin{array}{c}0.1 \\
(0.1)\end{array}$ & $\begin{array}{c}0.0 \\
(0.0)\end{array}$ \\
\hline event & $\begin{array}{c}12.1 \\
(22.5)\end{array}$ & $\begin{array}{c}7.4 \\
(16.2)\end{array}$ \\
\hline discourse & $\begin{array}{c}6.1 \\
(11.3)\end{array}$ & $\begin{array}{c}2.9 \\
(6.4)\end{array}$ \\
\hline cognition & $\begin{array}{c}10.2 \\
(18.9)\end{array}$ & $\begin{array}{c}6.9 \\
(15.1)\end{array}$ \\
\hline Attribute & $\begin{array}{c}21.7 \\
(40.4)\end{array}$ & $\begin{array}{c}27.3 \\
(59.8)\end{array}$ \\
\hline quality & $\begin{array}{c}3.0 \\
(5.7)\end{array}$ & $\begin{array}{c}3.6 \\
(7.9)\end{array}$ \\
\hline manner & $\begin{array}{c}7.0 \\
(13.0)\end{array}$ & $\begin{array}{c}9.2 \\
(20.2)\end{array}$ \\
\hline status & $\begin{array}{c}11.7 \\
(21.7)\end{array}$ & $\begin{array}{c}14.5 \\
(31.7)\end{array}$ \\
\hline Relation & $\begin{array}{c}3.6 \\
(6.7)\end{array}$ & $\begin{array}{c}1.1 \\
(2.5)\end{array}$ \\
\hline General Total & $\begin{array}{l}53.7 \\
(100)\end{array}$ & $\begin{array}{r}45.6 \\
(100)\end{array}$ \\
\hline
\end{tabular}


The entity category stands out in comparison. Except the object group, L2 students make significantly less use of the stance nouns in the event, discourse and cognition groups than L1 students. There are 7.4 cases of "event" stance nouns per 10,000 words in L2 students' writing against 12.1 cases in $L 1$ students' texts $(L L=1.25, p<0.01)$; 2.9 cases of "discourse" stance nouns in L2 students' writing against 6.1 cases in L1 students' writing ( $L L=1.23, p<0.01) ; 6.9$ occurrences of "cognition" stance nouns in L2 students" writing against 10.2 occurrences in L1 students' writing $(L L=0.71, p<0.01)$. Fewer instances of the entity category by $\mathrm{L} 2$ students imply that compared with L1 American students L2 learners are perhaps in a weaker position to define a knowledge source and the world in a second language, which requires a higher language proficiency to project such a stance.

Furthermore, L2 students' less frequent use of these event, discourse and cognition nouns would undermine the students' ability to fulfill the generic convention of argumentative essays in argument construction. Argumentative essays are "argumentative or expository in character, i.e. besides presenting facts, they have the aim to explain, analyze and interpret these facts and, usually, to argue for a certain standpoint" (Altenberg \& Tapper, 1998, p. 83). This generic convention and rhetorical practice may expect the proposition and perspective in an essay to be built on factual events. By foregrounding the event, discourse and cognition groups in the nominalized stance construction, L1 students get to highlight their demonstration of facts, propositions and standpoints to their advantages in building their argument and gaining claim plausibility, as seen in examples (13) $-(16)$.

(13) We did not experience many problems during my seventh and eighth grade years partly due to the fact that the number of black students compared to the number of white students was very low and many black students felt like they had to make friends with the white students in order to fit in. $<$ L1 $>$

(14) The act of trying to force an unwilling person to digest the religious philosophy of another may lead to an uncomfortable educational setting that would hinder learning and social growth. $<$ L1 $>$

(15) Designers make outfits that infer the instabilities people have in order to get people to buy their clothes with the hopes of expressing the style one wants to portray. $<$ L1 $>$

(16) By using a case study conducted in 1970 the supporters of censorship strengthen their argument about how impressionable young people are because programs in 1970, while maybe not all fit for children, were still censored ten times more than the shows of today. $<$ L1 $>$

While there is no significant difference in the attribute category between L1 and L2 students' writing, the attribute category accounts for the highest percentage of all stance nouns in L2 students' writing while L1 students make the most use of stance nouns in the entity category. This difference 
likely indicates L2 students' propensity to express their attitudinal evaluation and value-laden judgement of entity's attributes. Here are some examples.

(17) At last, it is our loss that we can't get the pleasures they should have produced to us. $<$ L2 $>$

(18) With these three advantages of reading a book, you may support my opinion that books will never be substituted by Internet. <L2>

(19) It gives them a chance to decide how they will spend their remaining time. $<$ L2>

Stance nouns in the relation category are used approximately 3.2 times less by L2 students than L1 students $(L L=1.45, p<0.01)$. Narration on relations between entities, no matter whether they are events, discourse or cognition, can open up discursive space for writers to extend discussion and argue for a further viewpoint, as seen in the examples below. Therefore, L2 students' less frequent use of the Noun Complement construction to set up relations between entities could undercut their opportunities to establish discursive space for further elaboration and discussion.

(20) The supporters then stress that nuclear power is very cost efficient in the long run, and the reason that it requires such a huge capital investment is because it will then run safely and efficiently for many years. $<\mathrm{L} 1>$

(21) We should keep a friendly attitude towards animals on the ground that the earth is the common and harmonious environment for both human beings and animals. Life is equal not only to human being but also to animals, we should respect the animals' lives. $<$ L2 $>$

(22) Once again, the consequences of giving a child back to the biological parents vary from one family to the next. Proponents attempt to generalize, and by not realizing that there are going to be differences in each cases, their claim is weakened. $<$ L1 $>$

When turning to the lexical range of stance nouns, interesting differences arise. Table 3 below shows the lexical range of stance nouns measured by comparing the frequencies of each type of stance nouns between L1 and L2 students' writing at different cut-off points. For the first cut-off point (over 60), L2 learners figure remarkably by their use of a single type for 67 times which accounts for $15 \%$ of all stance nouns whereas L1 students do not have such a high reliance on a single type for over 60 times. However, at other less high frequency cut-off points L1 students almost always use a wider range of stance nouns than L2 learners and such a trend becomes clear as the list goes down. This indicates that L2 students use a narrower range of stance nouns and therefore fall back on certain fairly familiar options. For example, in the discourse group there are 18 types of stance nouns in L1 students' texts but L2 learners have only 7 types and the noun "conclusion" is used 21 times, which makes up 75\% of the discourse group (totally 28 cases in the 
discourse group).

Table 3 Range of stance noun types between L1 and L2 students' writing

\begin{tabular}{ccc}
\hline & L1 students & L2 students \\
\hline over 60 & 0 & 1 \\
$50 \sim 59$ & 1 & 0 \\
$40 \sim 49$ & 1 & 0 \\
$30 \sim 39$ & 1 & 1 \\
$20 \sim 29$ & 0 & 3 \\
$10 \sim 19$ & 8 & 7 \\
$5 \sim 9$ & 11 & 9 \\
$2 \sim 4$ & 48 & 31 \\
1 & 74 & 64 \\
\hline
\end{tabular}

Hasselgren (1994) refers to L2 learners' reliance on certain frequent and familiar words as the "lexical teddy bears" phenomenon. A further look into the five most frequent stance nouns which are related to the conception of "argumentation" essays shows that conclusion, opinion, idea, view and thought are featured in L2 students' essays in contrast to idea, argument, claim, debate, and opposition in L1 students' texts. The most familiar and frequent discourse and cognition stance nouns used by L2 students, or their "lexical teddy bears", are pragmatically vague and void of illocutionary force, which Rundell and Ham (1994) have described as "default terms". Thus discussion and argument which are built on them are difficult to rhetorically develop to a further standpoint. In contrast, L1 students' lexicon, argument, claim, debate and opposition carry illocutionary force and perform certain speech acts, which enables them to formulate argumentation and extend the discussions and arguments further. We can get a sense of this difference in the following examples.

(23) Nowadays, some may hold the opinion that education is a life-long process. $<\mathrm{L} 2>$

(24) As to this problem, we should teach people that the development of our country relies on education and enforce compulsory education, we should always hold the view that wherever we stay, or whenever we are, we ought to obtain knowledge to improve ourselves. $<$ L2 $>$

(25) Advocates could strengthen their argument by addressing the opponents' claim that quotas reinforce black failure. Proponents need to argue that the effects of discrimination without quotas would be worse than the minor failures that occur because they are expected to. $<$ L1 $>$

(26) This statement also reflects on the previous arguments that the family will also 
feel great pain due to their loved one's suicide. This suffering for others means that the person should not feel suffering for their own religion but also for others as well. $<\mathrm{L} 1>$

(27) The debate over whether or not Marijuana should be legalized has been around since the sixties, and people today are realizing that it is certainly an issue that will not go away. $<$ L1 $>$

\subsection{Complement structures}

As was introduced in Section 2, in the Noun Complement construction a stance head noun takes a nominal complement either in the form of that clause, to-infinitive, of-prepositional or preposition plus wh- clause, but the frequencies of these complement structures differ across L1 and L2 students' writing, as is shown in Figure 1. These two groups of students make similarly frequent use of toinfinitive and of-prepositional structures but both that clause and preposition plus wh-clause are found significantly less frequent in L2 students' texts. There are 188 cases of that clause and 77 cases of preposition plus wh-clause in L1 students' writing with only 130 cases of that clause and 16 cases of preposition plus wh- clause in L2 learners' writing ( $L L=11.89, p<0.01 ; L L=44.82, p$ $<0.01)$.

Figure 1 Variation of syntactic structures across L1 and L2 students' writing

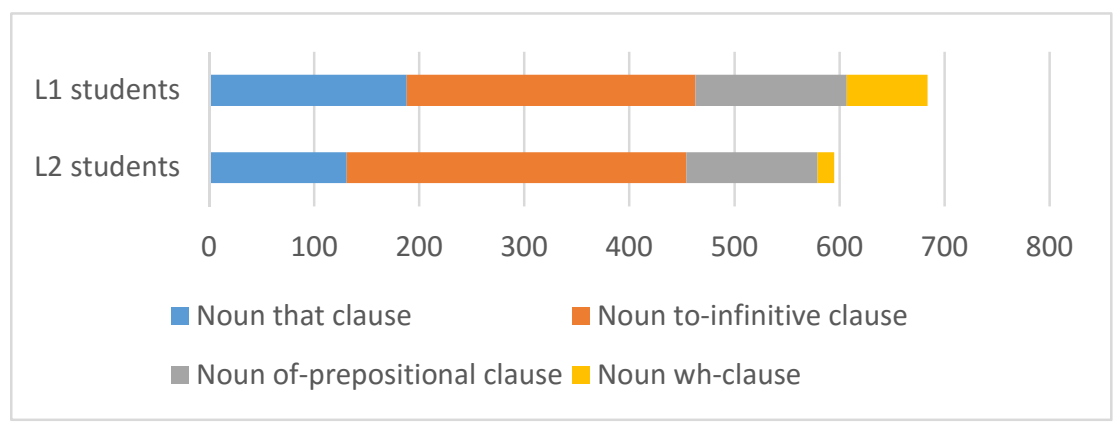

While all four of these structures involve nominalization, they may require different syntactic complexity and linguistic proficiency in the process. As for to-infinitive and of-prepositional structures, what is packed and nominalized normally is an action with no participant agency. But that clause and preposition plus wh-clause require a nominalization of an event where a participant agent carries out an action, which requires a more complicated language use and thus a higher linguistic proficiency. This difference can be seen in example (28) - (31).

(28) This demonstrates the powerful's ability to dictate the people in the society's values and behaviors. $<$ L1 $>$

(29) At the same time, we contribute to the movement of protecting environment. $<$ L2>

(30) there should not be a great controversy over whether students could utilize time 
after school to form a prayer group, a Bible or Koran study group. $<$ L1 $>$

(31) Advocates of affirmative action need to be aware of the opponents' statement

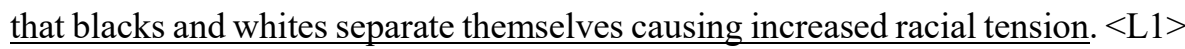

In addition, only 18 erroneous uses of either that clause or preposition plus wh-clause were found in L2 students' writing. Errors are exemplified below. This likely means that L2 students prefer to avoid using these two structures rather than make wrong attempts, which is described as “avoidance strategies" in L2 students' preference (Ellis, 1994, p. 185).

(32) In order to prove that she was natural, she even went to hospital to get a certificate that she never received such kind of operation. $<$ L2 $>$

(33) Government should enlarge education that more and more young people to gain chance which we study. $<$ L2 $>$

\subsection{Discoursal level}

When the concordance lines were expanded to larger stretches of discourse, it was interesting to note that L1 students frequently yoked together the event and discourse or the event and cognition groups of the Noun Complement construction. In this way, factual events provide argumentative grounds and support for the nearby discoursal statements or cognitive viewpoints. As we can see in the examples below, such integration enables writers to enhance the building of strong arguments but also makes the theme in discussion coherent and acceptable to the extent of "reinforc[ing] the reader's acceptance of the evidential weight" of the writer's claim (Hyland, 2007, p. 281).

(34) The main claim of deterrence focuses upon the idea that an individual is less likely to commit a serious crime when he or she is aware that the resulting penalty may be death. It is a known fact that for most people, the biggest fear in life is the fear of death. $<$ L1 $>$

(35) Some poll writers had a good argument that Florida State could have jumped Alabama in the polls because near the end of the regular season, Alabama struggled to the Florida Gators, a team that Florida State dismantled a week earlier. But the poll writers couldn't overlook the fact that Florida State had one loss while Alabama was still undefeated. $<$ L1 $>$

(36) By the advocates utilizing information about censorship in protection with the children they make a claim that children come first. Due to their views, a proponent might rebut that statement with the fact that some parents use the television as the baby sitter, not monitoring what their children see, so should the child be punished for the negligence of the parent. $<\mathrm{L} 1>$

(37) By using recent examples of how the government allows the networks to do whatever they please with the contents of their shows and how people are 
becoming numb to the provocative material in shows today, the advocates for censorship make their argument that television needs to be censored, well known and proven. $<$ L1 $>$

In contrast, it is relatively rare to see L2 learners make evident the formulation of their arguments by integrating the stance nouns in the discourse and cognition groups and those in the event group but more common to see their texts like the examples below. Although their argumentation may make some sense, it would become more clear to the readers that factual grounds are underscored to certify the ideas or conclusions proposed if the L2 writers in these extracts had brought in the spotlight a bond of the "conclusion" and "idea" with stance nouns in the event group. This sleight of hand not only helps to conjure up coherent warrants between claims and factual grounds (Qin \& Karabacak, 2010; Wingate, 2012), but also shows writers' care for readers' rhetorical expectation in comprehending argumentative essays. Thus as Nesi \& Moreton comment on a similar type of stance nouns, "even at an advanced level, students would benefit from greater awareness of their communicative potential and appropriate use" (2012, p. 141).

(38) Some people who don't agree this opinion may mistake the definition of education. They think that education only means studying in school. With leaving the school, the education stops. But as long as there existing new things we don't know, we need to learn.

So, I can draw the conclusion that education is a life-long process, and it's more of a case of making my schooling a part of my education. I never stop to learn. $<$ L2 $>$

(39) However, the idea that girls are supposed to stay at home and work within the family is not realistic. Men and women should enjoy equal rights. Girls also have the right to work outside and fulfill their own dreams. Girls can also undertake various activities involving scientific or technological creativity in the same way that boys do. $<$ L2 $>$

(40) University education offers more than the knowledge in textbooks. It invites us to care more about society and think about the world, therefore, form our worldview. This is the guidance for the rest of our lives. It determines the career we like to enter and more importantly, the way we choose to live. Viewed in this light, the idea that university education is just to prepare students for employment is definitely improper. It falsely narrows down the function of university education which includes a fairly wide range. $<$ L2 $>$

\subsection{Pre-modifications to stance nouns}

As was introduced above, the Noun Complement construction allows a writer to reinforce his or her stance expression through pre-modifications to stance nouns. In this respect, remarkable 
differences were also observed across L1 and L2 students' writing in the focused examination of attitudinal evaluation and self-mention as pre-modifiers. As is shown in Figure 2, L2 students give their attitudinal evaluation almost 2 times more than $L 1$ students $(L L=7.53, p<0.01)$ and the frequency of self-mention (my and our) in L2 students' essays is 9 times that of L1 equivalence ( $L L$ $=21.58, p<0.01)$.

Figure 2 frequencies of attitudinal evaluation and self-mention in pre-modification to stance nouns across L1 and L2 students' writing

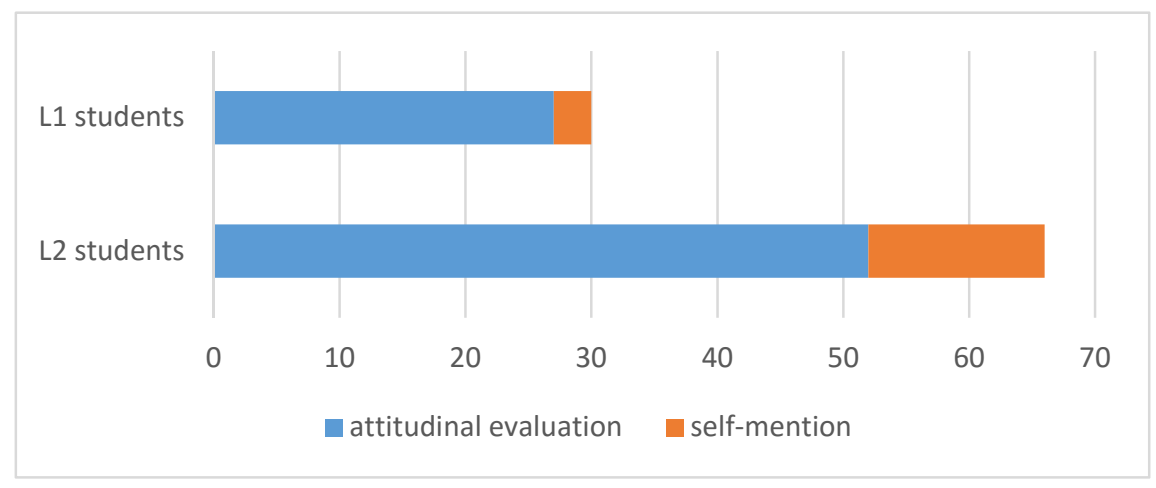

Compared with stance nouns, these pre-modifiers are more associated with personal involvement because such pre-modification shows a writer's attitudinal feeling and his or her overt presence in texts (Hunston, \& Thompson, 2000). As for the argumentative essays in this study, personal affect and persuasion are not typical and impersonal argumentation is generally favored (Nesi \& Gardner, 2012; Zhang, 2004). We can see from the following examples that L2 students are more inclined to stamp their personal affect on the stance noun they have selected.

(41) Cooperation being called for furnishes children with wonderful chance to learn from their fellows, so as to improve themselves. $<$ L2 $>$

(42) By my experience, these major problems include: poor mental health, loss of values and unfair opportunity of receiving education. $<$ L2 $>$

(43) All in all, I have a strong belief that our environment will be better and better through all the efforts of all the human being. $<$ L2 $>$

(44) All of us should take our own responsibility to balance the situation. $<$ L2 $>$

(45) Taking into account all the factors above, I can arrive at $\underline{m y}$ conclusion that high technology contributes to the improvement of our life. $<$ L2 $>$

Although this is a complex issue, it is possible that their frequent investment of attitudinal affect and their over-presentation of self-visibility may deviate from readers' expectation for argumentative essays, leading potentially to readers' suspicion of the argument's credibility.

\section{Further discussion}


This comparative investigation shows that Chinese English majors used significantly less of the Noun Complement construction especially in the event, discourse and cognition types of stance nouns, which are bound up with the generic conventions of argumentative essays, while applying more attitudinally evaluative and personal possessive pre-modifications to the stance nouns in the construction.

On the one hand, this might be caused by L2 students' lack of enough awareness of academic register and genre conventions (Altenberg \& Tapper, 1998; Hyland \& Milton, 1997). Readers of argumentative essays expect the writer's claim and argument to be based more on evidential facts than personal and affective involvement (Qin \& Karabacak, 2010; Wu, 2007). Besides, misinformed writing instruction is likely another reason which exerts indiscriminate emphasis on personal expression of attitudinal stance, as one of the Chinese university student informants said in Chen (2014)'s ethnographic study "teachers asked us to express ourselves in fancy words like 'gentle breeze" $"$.

On the other hand, L2 learners' limited writing lexicon and Chinese language influence could be reasons for these learners' infelicity in the use of the Noun Complement structure. L2 learners have limited lexical range at their writing command which tend to be vague and lacking in nuance (Cobb, 2003; Hinkel, 2004). This may lead L2 students to project their stance of how to define and frame knowledge source, argumentation and the world less tactfully. Furthermore, their Chinese language backgrounds and experiences can also be influencing factors. Chinese language has been under the influence of "worldly unity" philosophy and prefers "generalized and holistic" words (Hu, $2005)^{5}$ and such a mother tongue experience may induce L2 learners to opt for pragmatically vague vocabulary. Furthermore, the Noun Complement construction is a typical English syntactic structure where a head noun subsequently takes its specific lexicalization but the Chinese language gives specific lexicalization before its head noun. Such a syntactic contrast would make L2 learners unaccustomed to and thus avoid using this post-complement structure. Take another sentence from L2 students' writing for example. "Many people have the feeling that work is more stressful and leisurely than in the past." It is English language's convention that puts full specific lexicalization after the head noun. But a Chinese language way to write the above sentence could be:

许多人有一种工作比以前压力更大、更随意的感觉。

(Many people have a "work is more stressful and leisurely than in the past" feeling.)

\section{Conclusion}

This study has shown that the Noun Complement structure is a powerful nominal stance

\footnotetext{
4 Chen (2014) undertook an ethnographic investigation into the literacy practices in academic writing of undergraduate students in English major in China, a similar population to the L2 students in the current study.

${ }^{5} \mathrm{Hu}(2005$, p. 54) gave an interesting example: when it comes to “说 (speak)”, English language has a variety of related lexical choices such as grunt, exclaim, announce, shout, whisper, insist, speak, scream and address while Chinese language tends to use this only one generalized word “说” while specifying it with adverbial prior adjunct such as 嘟嘟囔囔地说 (grumblingly speak), 低声地说 (whisperingly speak), 大声地说 (loudly speak) and 坚 定地说 (affirmatively speak). So Chinese students always think of and use the only one “说” no matter in written or spoken Chinese.
} 
construction which affords writers opportunities to express their stance on the propositional information unfolded in the complement. The stance given and foregrounded through this construction is conducive to the construction and development of argument. It also relates to students' advanced academic language proficiency which is of importance to students' writing for academic purposes. However, through a corpus-based comparative interlanguage analysis, it is found that L2 students, even English majors at tertiary level, exhibit problems in their use of nominalized forms and stance projection in argumentation. L2 students make less use of this construction to mark and define factual events, discoursal acts and cognitive beliefs and therefore would lose rhetorical chances to present, analyze and interpret facts and to reinforce their construction of argument. But their highly frequent use of value-laden evaluative stance nouns in the attribute category and their personal presence and attitudinal investment in the pre-modifications in the construction may be less expected in many academic argumentative writing contexts, though there are surely exceptions.

The difficulties that L2 students find in the use of the Noun Complement complex could be attributed to their limited writing lexicon which tends to be pragmatically vague and bare of illocutionary force, their L1 Chinese language influence, their lack of sufficient awareness of academic register and genre and the misinformed writing instruction they receive. No matter what the causes, however, remedies are needed to address their unintended problems in the use of this construction. Firstly, students need to expand their writing repertoire in conveying stance. Longman Language Activator is a good reference which is corpus-informed and designed in a conceptuallyorganized pattern. It provides English learners with writing network from basic-level category to more "semantically or connotationally" nuanced options (Rundell \& Ham, 1994, p. 174). For example, learners can find from the entry of "opinion" a range of more specific near-synonyms such as "attitude", "consensus" and "stance".

Furthermore, it is necessary for writing instructors to illustrate the rhetorical potentials afforded by the Noun Complement structure as a stance construction in argument building, show the syntactic differences of this structure between Chinese and English and present lexical argumentative (un)specificity differences between L1 and L2 students' use of stance nouns for example those found in this study. However, a word of caution should be given that it is not wise to encourage students to use the Noun Complement construction as often as possible. This is because the use of this construction is sensitive to register and genre (Biber et al, 1999). For example, it seems inappropriate to frequently use this construction in conversational genres. Therefore, writing instructors are also recommended to sensitize English learners to register or genre conventions, one case of which is that factual grounds and warrants are expected in academic argumentative writing while writers' personal involvement may be more acceptable in narratives and reflection essays.

Moreover, this study uncovers one more way by which writers can evaluate the material they present and carve out a personal position. By foregrounding the writer's stance, the Noun Complement construction is a powerful way of influencing how readers interpret and understand the information they convey and setting up the writer's argument for further negotiation. This 
contributes to the growing literature on stance in academic writing. My analyses show that stance is not only a lexical feature of discourse, but is also very much a grammatical phenomenon. Thus there are good reasons for including this nominal stance construction in academic writing courses and explicit instruction in the rhetorical and stancetaking affordances of this construction can equip students with a wider range of stance devices.

This paper compares the L1 and L2 student corpora by virtue of the similar topics and the students' similar age and educational level, but the difference in L1 and L2 essay length might influence students' use of this stance construction at discoursal level. Another limitation must be acknowledged that given the lack of detailed contextual information about the essays such as task aims and marking criteria, not much can be made of the overuse and underuse by L2 students. In addition, this paper's speculation of the influence of L1 Chinese language on the L2 learners' use of this structure is tentative and thus future studies are also needed to testify such a L1 influence, which may benefit from a comparative interlanguage analysis across more corpora of English learners from more different nationalities or language families.

\section{References}

Ädel, A. (2006). Metadiscourse in L1 and L2 English. Amsterdam: John Benjamins.

Altenberg, B., \& Tapper, M. (1998). The use of adverbial connectors in advanced Swedish learners' written English. In S. Granger (Ed.), Learner English on Computer (pp. 80-93). Harlow: Longman.

Anthony, L. (2012). AntConc (3.3. 5u) [Computer Software]. Tokyo: Waseda University.

Author. (2015).

Barton, E. L. (1993). Evidentials, argumentation, and epistemological stance. College English, 745-769.

Biber, D. (2006). Stance in spoken and written university registers. Journal of English for Academic Purposes, 5(2), 97-116.

Biber, D., Johansson, S., Leech, G., Conrad, S., Finegan, E., \& Quirk, R. (1999). Longman Grammar of Written and Spoken English. Harlow: Longman.

Charles, M. (2007). Argument or evidence? Disciplinary variation in the use of the Noun that pattern in stance construction. English for Specific Purposes, 26(2), 203-218.

Chen, Q. S. (2014). Exploring the literacy practices of undergraduate English majors' academic writing in China. Paper presented at the Postgraduate Research Conference 2013-2014, Hong Kong.

Cobb, T. (2003). Analyzing late interlanguage with learner corpora: Quebec replications of three European studies. Canadian Modern Language Review/La Revue canadienne des langues vivantes, 59(3), 393-424.

Cummins, J. (1984). Wanted: A theoretical framework for relating language proficiency to academic achievement among bilingual students. In C. Rivera (Ed.), Language Proficiency and Academic Achievement (Vol. 10, pp. 2-19). Clevedon: Multilingual Matters.

Ellis, R. (1994). The Study of Second Language Acquisition. Oxford: Oxford University Press.

Flowerdew, J. (2003). Signalling nouns in discourse. English for Specific Purposes, 22(4), 329-346. 
Flowerdew, J. (2006). Use of signalling nouns in a learner corpus. International Journal of Corpus Linguistics, 11(3), 345-362.

Francis, G. (1986). Anaphoric Nouns. Birmingham: University of Birmingham.

Francis, G. (1994). Labelling discourse: An aspect of nominal-group lexical cohesion. In M. Coulthard (Ed.), Advances in Written Text Analysis (pp. 83-101). London: Routledge.

Granger, S. (1998). The computerized learner corpus: A versatile new source of data for SLA research. In S. Granger (Ed.), Learner English on Computer. Harlow: Longman.

Grant, L., \& Ginther, A. (2000). Using computer-tagged linguistic features to describe L2 writing differences. Journal of Second Language Writing, 9(2), 123-145.

Halliday, M. A. K., \& Hasan, R. (1976). Cohesion in English. London: Longman.

Halliday, M. A. K., \& Matthiessen, C. M. (2004). An Introduction to Functional Grammar (3rd ed.). London: Arnold.

Hasselgren, A. (1994). Lexical teddy bears and advanced learners: A study into the ways Norwegian students cope with English vocabulary. International Journal of Applied Linguistics, 4(2), 237 258.

Hinkel, E. (2004). Teaching Academic ESL Writing: Practical techiniques in vocabulary \& grammar. Mahwah, NJ: Lawrence Erlbaum.

Holmes, J. (1988). Doubt and certainty in ESL textbooks. Applied Linguistics, 9(1), 21-44.

Hu, Y. Y. (2005). Western and Chinese thinking differences and English learning. Digest of Management Science(7), 53-54.

Hunston, S., \& Thompson, G. (2000). Evaluation in Text: Authorial stance and the construction of discourse. Oxford: Oxford University Press.

Hyland, K. (2005). Metadiscourse: Exploring interaction in writing. London: Continuum.

Hyland, K. (2007). Applying a gloss: Exemplifying and reformulating in academic discourse. Applied Linguistics, 28(2), 266-285.

Hyland, K., \& Guinda, C. S. (2012). Stance and Voice in Written Academic Genres. Basingstoke: Palgrave Macmillan.

Hyland, K., \& Milton, J. (1997). Qualification and certainty in L1 and L2 students' writing. Journal of Second Language Writing, 6(2), 183-205.

Hyland, K., \& Tse, P. (2005). Hooking the reader: A corpus study of evaluative that in abstracts. English for Specific Purposes, 24(2), 123-139.

Ivanič, R. (1991). Nouns in search of a context: A study of nouns with both open-and closed-system characteristics. IRAL, 29(2), 93-114.

Labov, W. (1972). Language in the Inner City: Studies in the Black English vernacular. Pennsylvania: University of Pennsylvania Press.

Lancaster, Z. (2014). Exploring valued patterns of stance in upper-level student writing in the disciplines. Written Communication, 31(1), 27-57.

Kuckartz, U. (2007). MAXQDA: Qualitative data analysis [Computer Software]. Berlin: VERBI Software. 
Martin, J. R., \& White, P. R. R. (2005). The Language of Evaluation: Appraisal in English. New York: Palgrave Macmillan.

McEnery, T., \& Kifle, N. A. (2002). Epistemic modality in argumentative essays of second-language writers. In J. Flowerdew (Ed.), Academic Discourse (pp. 182-195). London: Longman.

Nesi, H., \& Gardner, S. (2012). Genres across the Disciplines: Student writing in higher education. Cambridge: Cambridge University Press.

Nesi, H., \& Moreton, E. (2012). EFL/ESL writers and the use of shell nouns. In R. Tang (Ed.), Academic Writing in a Second or Foreign Language (pp. 126-145). London: Continuum.

Qin, J., \& Karabacak, E. (2010). The analysis of Toulmin elements in Chinese EFL university argumentative writing. System, 38(3), 444-456.

Ramanathan, V., \& Atkinson, D. (1999). Individualism, academic writing, and ESL writers. Journal of Second Language Writing, 8(1), 45-75.

Rundell, M., \& Ham, N. (1994). A new conceptual map of English. Paper presented at the The 6th EURALEX International Congress on Lexicography, Amsterdam.

Schmid, H.-J. (2000). English Abstract Nouns as Conceptual Shells: From corpus to cognition (Vol. 34). Berlin: Walter de Gruyter.

Tang, R. (2012). Academic Writing in a Second or Foreign Language. London: Continuum.

Winter, E. O. (1982). Towards a Contextual Grammar of English: The clause and its place in the definition of sentence. London: George Allen \& Unwin.

Wingate, U. (2012). 'Argument!'helping students understand what essay writing is about. Journal of English for Academic Purposes, 11(2), 145-154.

Wu, S. M. (2007). The use of engagement resources in high-and low-rated undergraduate geography essays. Journal of English for Academic Purposes, 6(3), 254-271.

Zhang, F. Q. (2004). A critical review of the marking criteria of TEM 4 writing test. Journal of the University of International Relations(4), 48-51. 


\section{Appendix: the topics covered in the argumentative essays}

1. L1 students' argumentative essays

Education

Moral values

Health

Nuclear power

Animal testing

Gender equality

Teenagers

Wealth

Orphanages

\section{L2 students' argumentative essays}

Education

Computer games

Modern technology

Animal protection

Cultural customs and modernization

Income disparity

Privacy of famous people

Environmental protection

Pressure

Moral values

Gender inequality
Capital punishment

Media

Welfare reforms

Suicide

Water pollution

Divorce

Football

Cultural stereotypes

Superstition

Thrift

Public facilities

Sports

Brain drain

Traffic and housing problems

Language learning

E-dictionaries

Competition or cooperation

The Youth

Campus accommodation 